\title{
EDUKASI MUSNAHKAN GIZI BURUK DI DESA MENGGALA, KABUPATEN LOMBOK UTARA, PROVINSI NUSA TENGGARA BARAT (DAERAH TERTINGGAL) MELALUI TERAPI MERDEKA MADU TRIGONA
}

\author{
Niswatun Asnawati ${ }^{1,2)}$, Muh. Efendi Jayadi ${ }^{1,2)}$, Salwa Afrilia ${ }^{1,2)}$, M. Sofyandi ${ }^{1,2)}$, Sri Wahyuni ${ }^{1,2)}$, \\ Jinan Estida Hayati Umajan ${ }^{1,2)}$, Sri Apriyanti ${ }^{1,2)}$, M. Abdul Hamid Zubair ${ }^{1,2)}$, Hikmah Nurul \\ Aslamiah ${ }^{1,2)}$, Desak Hartami Malik ${ }^{1,2)}$, Lalu Dedy Supriatna ${ }^{2)}$, Bahjatun Nadrati ${ }^{3)}$, Raudatul \\ Jannah $^{4)}$, Lalu Unsunnidhal')

\begin{abstract}
1)Dewan Perwakilan Mahasiswa, STIKES YARSI Mataram, Mataram, Nusa Tenggara Barat, Indonesia 2)Program Studi Sarjana IImu Keperawatan, STIKES YARSI Mataram, Mataram, Nusa Tenggara Barat, Indonesia 3)Program Studi Diploma III Keperawatan, STIKES YARSI Mataram, Mataram, Nusa Tenggara Barat, Indonesia 4)Program Studi Sarjana Kebidanan, STIKES YARSI Mataram, Mataram, Nusa Tenggara Barat, Indonesia
\end{abstract} \\ Corresponding author : Lalu Unsunnidhal \\ E-mail : unsun.nidhal@mail.ugm.ac.id
}

Diterima 26 Oktober 2021, Disetujui 22 Desember 2021

\begin{abstract}
ABSTRAK
Program pengabdian ini ditujukan untuk memberikan informasi dan menumbuhkan kesadaran masyarakat di Desa Menggala, Kabupaten Lombok Utara, Provinsi Nusa Tenggara Barat akan potensi madu trigona dan pengembangan budidayanya dalam menyelesaikan masalah gizi buruk. Usaha peningkatan kualitas sumber daya manusia dari Desa Menggala terkendala rendahnya kualitas kesehatan penduduk di Desa Menggala, hal ini dapat diketahui dari banyaknya penduduk di Desa Menggala memiliki status gizi buruk. Program pengabdian ini dilakukan untuk memperbaiki status gizi buruk dari masyarakat di Desa Menggala. Usaha peningkatan tersebut dilakukan dengan mengadakan edukasi, diskusi tentang potensi madu trigona dan pengembangan budidayanya dalam menyelesaikan masalah gizi buruk. Tahapan pelaksaanaan kegiatan meliputi observasi awal (1 September 2021) dan edukasi (2 September 2021). Walaupun tidak seluruh anggota masyarakat di Desa Menggala dikumpulkan untuk edukasi dikarenakan mengikuti protokol Covid-19, namun pada pelaksanaannya para keluarga yang memiliki anggota keluarga berstatus gizi buruk dan kader-kader kesehatan desa dapat hadir dan mengikuti kegiatan tersebut, selain itu, antusias dan respon positif dari para peserta tersebut menghasilkan berjalannya dengan baik program pengabdian ini.
\end{abstract}

Kata kunci: edukasi; gizi buruk; terapi merdeka madu trigona; desa menggala.

\begin{abstract}
This service program is intended to provide information and raise public awareness in Menggala Village, North Lombok Regency, West Nusa Tenggara Province about the potential of Trigona honey and the development of its cultivation in solving the problem of malnutrition. Efforts to improve the quality of human resources from Menggala Village are constrained by the low quality of health of the residents in Menggala Village, this can be seen from the large number of residents in Menggala Village who have poor nutritional status. This service program is carried out to improve the poor nutritional status of the community in Menggala Village. The improvement efforts were carried out by conducting education, discussing the potential of Trigona honey and developing its cultivation in solving the problem of malnutrition. The stages of implementing the activities include initial observation (1 September 2021) and education (2 September 2021). Although not all community members in Menggala Village were gathered for education because they followed the Covid-19 protocol, in practice, families with family members with poor nutritional status and village health cadres were able to attend and participate in the activity, in addition, enthusiastic and positive responses. of the participants produced their performance with this good program of service.
\end{abstract}

Keywords: education; malnutrition; trigona honey free therapy; menggala village.

\section{PENDAHULUAN}

Desa Menggala merupakan desa termuda di Kecamatan Pemenang, Kabupaten Lombok Utara, Provinsi Nusa Tenggara Barat, desa ini baru terbentuk per tanggal 22 Juni 2020 melalui Peraturan Daerah Kabupaten Lombok Utara Nomor 8 Tahun 2020 tentang Pembentukan Desa Menggala Kecamatan 
Pemenang Kabupaten Lombok Utara, yang dimana Kabupaten Lombok Utara sendiri pun masih digolongkan Daerah Tertinggal berdasarkan Peraturan Presiden Nomor 63 Tahun 2020 tentang Penetapan Daerah Tertinggal Tahun 2020-2024, sehingga menjadi desa termuda di daerah tertinggal merupakan tantangan tersendiri bagi Desa Menggala. Usaha peningkatan status dari daerah tertinggal ini dapat dilaksanakan dengan peningkatan kualitas sumber daya manusianya.

Usaha peningkatan kualitas sumber daya manusia dari Desa Menggala terkendala rendahnya kualitas kesehatan penduduk di Desa Menggala, hal ini dapat diketahui dari banyaknya penduduk di Desa Menggala memiliki status gizi buruk. Berdasarkan survey lapangan dan wawancara yang telah dilakukan di Puskesmas Desa terdekat (Puskesmas Pemenang) telah diketahui 17 penduduk dari Desa Menggala memiliki status gizi buruk. Permasalahan status gizi buruk merupakan permasalahan yang cukup lama yang hingga kini belum dapat terselesaikan. Hal ini dapat diketahui berdasarkan data jumlah frekuensi gizi buruk per kecamatan di Kabupaten Lombok Utara pada tahun 2010, Kecamatan Pemenang yang merupakan kecamatan dari Desa Menggala memiliki frekuensi gizi buruk sebanyak $27 \%$ dari frekuensi gizi buruk seluruh Kabupaten Lombok Utara (Hafizah \& Lutfi Ghazali, 2010).

Potensi sumber daya alam yang dimiliki Desa Menggala apabila dikelola dengan kreatif dan efisien dapat menjadi solusi untuk menyelesaikan permasalahan gizi buruk yang dihadapi. Desa Menggala memiliki batas wilayah sebagai berikut: a) Batas Utara adalah Desa Pemenang Barat; b) Batas Timur adalah Desa Pemenang Timur; c) Batas Selatan adalah Kabupaten Lombok Barat dan d) Batas Barat adalah Desa Malaka, sedangkan luas wilayah Desa Menggala sebesar $2.755 \mathrm{Ha} 2$ (Kabupaten Lombok Utara, 2020), dengan batas wilayah dan luas wilayah ini sehingga Hutan Lindung Pusuk Lombok Utara yang bertempat di sisi selatan dan berbatasan langsung dengan Kabupaten Lombok Barat termasuk wilayah dari Desa Menggala. Potensi kondisi wilayah dari Desa Menggala sangatlah tepat apabila dikembangkan budidaya lebah trigona karena menyediakan nektar sebagai pakannya dan udara maupun iklim yang dibutuhkan lebah trigona untuk berkembang dan memproduksi madu trigona.

Potensi sumber daya manusia dari Desa Menggala juga mendukung dalam pelaksanaan pengembangan lebah trigona untuk menghasilkan produk madu trigona. Desa Menggala memiliki jumlah penduduk sebesar
6.922 jiwa dengan 2.133 kepala keluarga (Kabupaten Lombok Utara, 2020). Mayoritas pekerjaan yang dilaksanakan oleh penduduk Desa Menggala adalah bertani dan beternak (Mashur et al., 2019; Unsunnidhal \& Suryawati, 2020a; Unsunnidhal \& Suryawati, 2020b), sehingga tanaman pertanian atau pun kemampuan beternak para penduduk dapat menjadi modal awal untuk pengembangan lebah trigona sehingga menghasilkan madu trigona.

Madu trigona sendiri menjadi solusi dari permasalahan gizi buruk yang dialami penduduk Desa Menggala. Madu Trigona telah diketahui merupakan salah satu sumber makanan yang baik karena mengandung asam amino, karbohidrat, protein, vitamin serta mineral yang mudah diserap oleh sel-sel tubuh. Madu mengandung sejumlah mineral seperti magnesium, kalium, potasium, sodium, klorin, sulfur, besi, fosfat dan vitamin, seperti vitamin $E$, vitamin C, vitamin B1, B2 dan B6 (Agussalim, 2020). Selain itu, Madu Trigona memiliki kandungan vitamin $\mathrm{C}$ yang berfungsi sebagai antibiotik, antioksidan dan serta untuk meningkatkan sistem imun atau kekebalan tubuh, serta kandungan vitamin $A$, besi $(F e)$, dan vitamin B12 yang berfungsi sebagai pembentukan sel darah merah dan hemoglobin dapat mengobati penyakit anemia yang diakibatkan kurang gizi bagi ibu hamil (Wulandari, 2015), madu trigona pun terbukti meningkatkan berat badan dan kadar hemoglobin pada balita (Nurmalasari, 2016), sehingga terapi pemberian madu trigona merupakan solusi tepat untuk memusnahkan permasalahan gizi buruk masyarakan Desa Menggala.

Terapi madu trigona yang merdeka dapat terwujud melalui edukasi dan pemberian informasi untuk transfer ilmu kepada masyarakat Desa Menggala terkait budidaya mandiri ternak lebah trigona yang menghasilkan madu trigona. Pemilihan edukasi dan pemberian informasi terkait budidaya lebah trigona untuk terapi merdeka ini sangat tepat sebagai sarana pengabdian (Unsunnidhal \& Dwi Prihantoko, Kurniawan Kusumawati, 2021; Unsunnidhal et al., 2021). Kondisi penduduk Desa Menggala yang mayoritas sebagai petani dan peternak akan mempercepat transfer ilmu dalam kaitan budidaya ternak lebah trigona. Sebagai informasi tambahan, budidaya lebah trigona juga sangatlah mudah, tidak memerlukan keterampilan khusus dan tidak memerlukan waktu yang lama dalam proses pembudidayaannya. 


\section{METODE}

Metode kegiatan pengabdian masyarakat yang telah dilaksanakan adalah pemberian edukasi dan diskusi (sharing informasi). Jumlah masyarakat Desa Menggala yang hadir dalam pengabdian masyarakat ini hanya 15 orang, hal ini dikarenakan mengikuti protokol Covid-19 yang tidak diperbolehkan mengumpulkan masa dalam jumlah yang banyak. Selain itu, kegiatan ini hanya berfokus pada para keluarga yang memiliki anggota keluarga berstatus gizi buruk dan kader-kader kesehatan desa. Tema pemberian edukasi dan diskusi (sharing informasi) yang telah dilaksanakan di Desa Menggala, Kecamatan Pemenang, Kabupaten Lombok Utara, Provinsi Nusa Tenggara Barat adalah edukasi musnahkan gizi buruk di Desa Menggala, Kecamatan Pemenang, Kabupaten Lombok Utara, Provinsi Nusa Tenggara Barat dengan hasil yang telah dicapai dari kegiatan pengabdian masyarakat ini adalah peningkatan pengetahuan masyarakat terkait budidaya lebah trigona dan pemanfaatan madunya untuk terapi merdeka untuk gizi buruk.

Pengabdian masyarakat ini dilaksanakan selama satu hari, yaitu pada tanggal 2 September 2021 untuk pelaksanaan edukasi dan diskusi. Pengabdian masyarakat ini dilaksanakan di Aula Desa Menggala, Kecamatan Pemenang, Kabupaten Lombok Utara, Provinsi Nusa Tenggara Barat. Namun, sebelum pelaksanaan kegiatan pengabdian masyarakat ini, telah dilaksanakan observasi awal tepatnya $\mathrm{H}-1$ sebelum hari pelaksanaan kegiatan. Observasi awal dilaksanakan untuk mengetahui faktor penyebab permasalahan di masyarakat dan gambaran awal wilayah (Unsunnidhal \& Dwi Prihantoko, Kurniawan Kusumawati, 2021; Unsunnidhal et al., 2021; Unsunnidhal \& Suryawati, 2020a; Unsunnidhal \& Suryawati, 2020b).

\section{HASIL DAN PEMBAHASAN}

Program pengabdian ini dilaksanakan sesuai dengan jadwal yang telah direncanakan yaitu tanggal 2 September 2021 untuk pelaksanaan edukasi berikut diskusi (sharing informasi) terkait musnahkan gizi buruk melalui terapi merdeka madu trigona. Sebelumnya telah dilaksanakan observasi awal yaitu pada tanggal 1 September 2021 untuk diskusi, survey lapangan pada masyarakat di Desa Menggala dan studi awal dalam kaitan menganalisis kebutuhan dan permasalahan yang dihadapi oleh masyarakat di Desa Menggala.

Pada hari kegiatan yaitu pada tanggal 1 September 2021, acara yang dilaksanakan adalah edukasi dan diskusi (sharing informasi) terkait memusnahkan gizi buruk melalui terapi merdeka madu trigona oleh Niswatun Asnawati. Materi yang diberikan meliputi potensi yang dimiliki desa untuk pengembangan madu trigona, bagaimana membudidaya lebah madu trigona dan manfaat dari madu tersebut untuk para penderita gizi buruk sehingga dapat meningkatkan status gizi dari gizi buruk yang berada di Desa Menggala. Para peserta juga memberikan respon positif terhadap materi yang diberikan. Hal ini terlihat dari para peserta yang sangat antusias untuk bertanya dan berdiskusi mengenai masalah-masalah yang sering dihadapi di lapangan pada sesi diskusi. Hal tersebut terdokumentasi sebagaimana pada Gambar 1 dan Gambar 2.

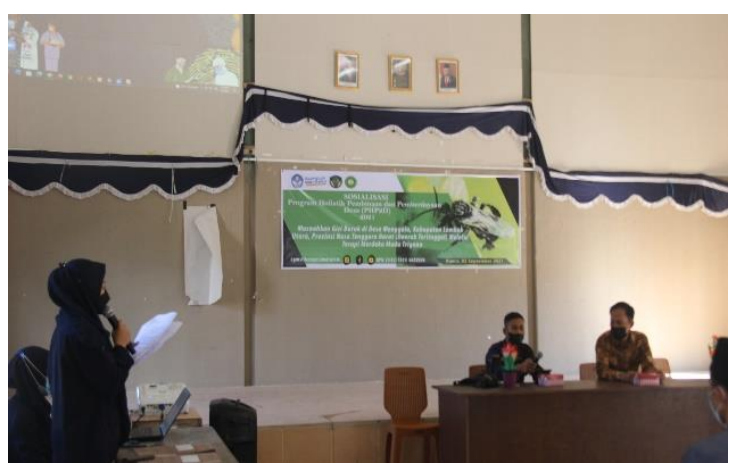

Gambar 1. Pemberian materi edukasi musnahkan gizi buruk dengan terapi merdeka madu trigona

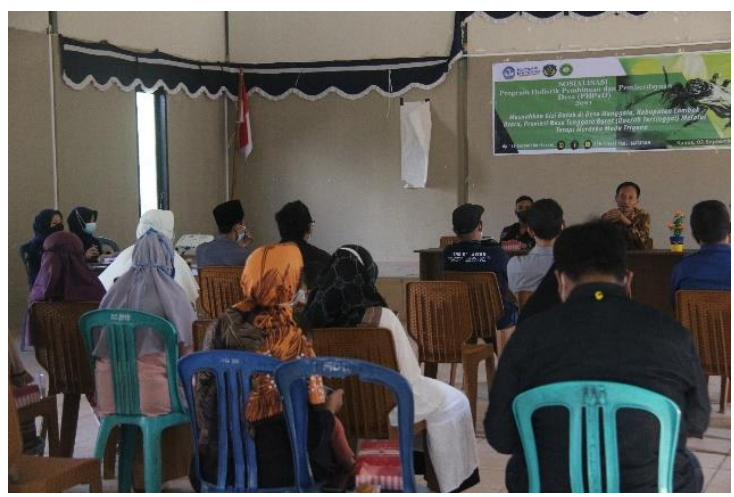

Gambar 2. Peserta antusias bertanya pada sesi diskusi

Kegiatan selanjutnya setelah edukasi dan diskusi adalah foto Bersama dan diskusi santai. Hal ini mengingat suasana pembatasan yang dikarenakan pandemic Covid-19 sehingga pelaksana kegiatan ini diharapkan dapat meningkatkan tali silaturahmi antara panitia dan peserta. Kegiatan ini terdokumentasi pada Gambar 3 dan Gambar 4. 


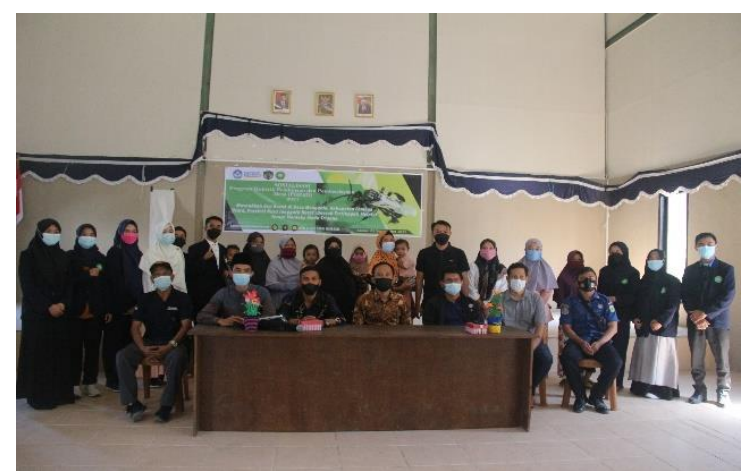

Gambar 3. Foto Bersama antara Panitia dan Peserta Kegiatan

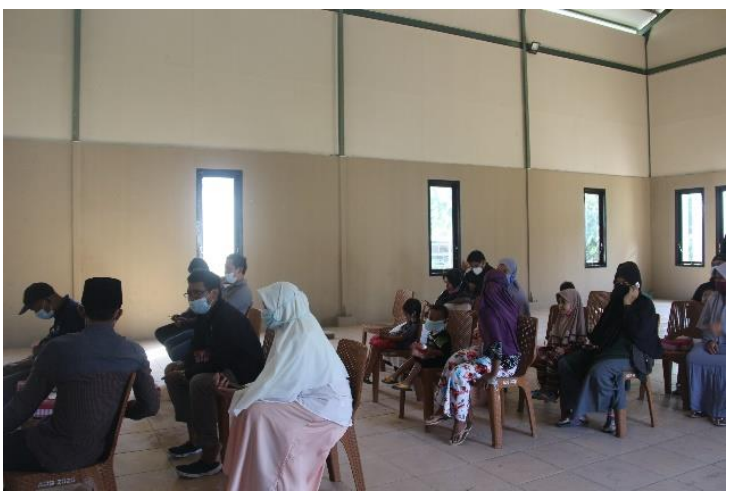

Gambar 4. Diskusi Santai antara Panitia dan Peserta Kegiatan

Selama kegiatan berlangsung, kendala utama adalah kurang maksimalnya peserta yang diundang. Hal ini dikarenakan protokol pandemik Covid-19 yang harus dilaksanakan. Selain itu, terganggunya komunikasi karena kewajiban pemakaian masker mengikuti protokol Covid-19, berkat antusias peserta acara pengabdian, acara pengabdian hari pertama dapat diselesaikan dengan baik.

\section{SIMPULAN DAN SARAN}

Kegiatan pengabdian edukasi musnahkan gizi buruk melalui terapi merdeka madu trigona telah dilaksanakan dan dapat berjalan dengan lancar. Dengan adanya pengabdian ini diharapkan para penderita gizi buruk di Desa Menggala dapat meningkatkan status gizinya dengan menerapkan terapi merdeka madu trigona. Saran untuk meningkatkan status gizi tersebut dapat melalui koordinasi internal. Koordinasi internal yang dimaksud dalam berdiskusi dengan kader kesehatan yang terdapat di desanya.

\section{DAFTAR RUJUKAN}

Agussalim (2020) DOMESTIKASI DAN BUDIDAYA LEBAH Tetragonula Laeviceps: EVALUASI POTENSI PRODUKSI DAN KUALITAS MADU SEBAGAI IMUNOMODULATOR.

Hafizah \& Lutfi Ghazali, P. (2010) Profil Gizi
Buruk Pada Balita Di Kabupaten Lombok Utara. JKKI, 2 (5), pp. 11-18.

Kabupaten Lombok Utara, P. D. (2020) Peraturan Daerah Kabupaten Lombok Utara Nomor 8 Tahun 2020.

Mashur, Oktaviana, D., Kholik \& Unsunnidhal, L. (2019) Implementation of Health Management of a Beef Catle Feed and the Collective Cage Based Smallholder Farming in Lombok Island. In: Proceedings of The 2nd International Conference on Bioscience, Biotechnology and Biometrics, 2019. Lombok: AIP Publishing, pp. 1-5.

Nurmalasari, Y. (2016) PERBEDAAN EFEKTIVITAS MADU DAN PROPOLIS TERHADAP KONDISI KESEHATAN PADA BALITA DI POSYANDU MAWAR VII KELURAHAN SIDODADI, KECAMATAN KEDATON BANDAR LAMPUNG TAHUN 2014. Jurnal IImu Kedokteran dan Kesehatan, 3 (2), pp. 724-739.

Unsunnidhal, L. \& Dwi Prihantoko, Kurniawan Kusumawati, A. (2021) PENYULUHAN PERILAKU SEHAT, EDUKASI PENTINGNYA MANAJEMEN KESEHATAN REPRODUKSI TERNAK POTONG DAN PENYERAHAN BANTUAN SEMBAKO COVID-19 DI KELOMPOK TERNAK SAPI POTONG "KALIMASODO", KARANGDUKUH, JOGONALAN, KLATEN, JAWA TENGAH. Lentera Jurnal. Jurnal Pengabdian, 1 (1), pp. 15-23.

Unsunnidhal, L., Dwi Prihantoko, K. \& Kusumawati, A. (2021) EDUKASI PENTINGNYA MANAJEMEN KESEHATAN REPRODUKSI TERNAK POTONG DAN PENYERAHAN BANTUAN SEMBAKO COVID-19 DI KELOMPOK TERNAK SAPI POTONG "KALIMASODO", KARANGDUKUH, JOGONALAN, KLATEN, JAWA TENGAH. SELAPARANG. Jurnal Pengabdian Masyarakat Berkemajuan, 4 (April), pp. 23-27.

Unsunnidhal, L. \& Suryawati, B. N. (2020a) Analisis Risiko Usaha Ternak Di Dusun Koloh Brora Dan Pengenalan Upaya Mitigasi Risiko Melalui Diversifikasi Usaha. Sasambo: Jurnal Abdimas (Journal of Community Service), 2 (2), pp. 64-69.

Unsunnidhal, L. \& Suryawati, B. N. (2020b) Penguatan Ekonomi Masyarakat Pasca Bencana Gempa Melalui Pendampingan Pembuatan Usaha Rumahan Di Pemenang Barat. Selaparang. Jurnal Pengabdian Masyarakat Berkemajuan, 3 (2), pp. 166-169. 
Wulandari, P. (2015) Honey To Prevent Iron Deficiency Anemia In Pregnancy. $J$ MAJORITY, 4 (3). 